\title{
The role of intraoperative radiation therapy in resectable pancreatic cancer: a systematic review and meta-analysis
}

Liang $\operatorname{Jin}^{\dagger}$, Ning Shi ${ }^{\dagger}$, Shiye Ruan, Baohua Hou, Yiping Zou, Xiongfeng Zou, Haosheng Jin ${ }^{*}$ and Zhixiang Jian ${ }^{*}$

\begin{abstract}
Purpose: Several studies investigating the role of intraoperative radiotherapy (IORT) in the treatment of resectable pancreatic cancer (PC) have been published; however, their results remain inconsistent. By conducting a systematic review and meta-analysis, this study aimed to compare clinical outcomes in patients with resectable PC who underwent surgery with or without IORT.
\end{abstract}

Methods and materials: The MEDLINE/PubMed, EMBASE, and Cochrane Library databases were searched to identify relevant studies published up to February 28, 2019. The main outcome measures included median survival time (MST), local recurrence (LR), postoperative complications, and operation-related mortality. Pooled effect estimates were obtained by performing a random-effects meta-analysis.

Results: A total of 1095 studies were screened for inclusion, of which 15 studies with 834 patients were included in the meta-analysis. Overall, 401 patients underwent pancreatic resection with IORT and 433 underwent surgery without IORT. The pooled analysis revealed that IORT group experienced favorable overall survival (median survival rate $[M S R], 1.20 ; 95 \%$ confidence interval $[C l], 1.06-1.37, P=0.005)$, compared with patients who did not receive IORT. Additionally, the pooled data showed a significantly reduced LR rate in the IORT group compared with that in the non-IORT group (relative risk [RR], $0.70 ; 95 \% \mathrm{Cl}, 0.51-0.97, P=0.03$ ). The incidences of postoperative complications ( $R R, 0.95 ; 95 \% \mathrm{Cl}, 0.73-1.23$ ) and operation-related mortality ( $R R, 1.07$; 95\% Cl, 0.44-2.63) were similar between the IORT and non-IORT groups.

Conclusion: IORT significantly improved locoregional control and overall survival in patients with resectable PC, without increasing postoperative complications and operation-related mortality rates.

Keywords: Resectable pancreatic cancer, Intraoperative radiotherapy, Median survival time, Local recurrence, Postoperative complications and operation-related mortality

\footnotetext{
*Correspondence: kinghaos@126.com; jzx_117@163.com

'Liang Jin and Ning Shi contributed equally to this work.

Department of General Surgery, Guangdong Provincial People's Hospital,

Guangdong Academy of Medical Sciences, Guangzhou 510080, China
}

(c) The Author(s). 2020 Open Access This article is licensed under a Creative Commons Attribution 4.0 International License, which permits use, sharing, adaptation, distribution and reproduction in any medium or format, as long as you give appropriate credit to the original author(s) and the source, provide a link to the Creative Commons licence, and indicate if changes were made. The images or other third party material in this article are included in the article's Creative Commons licence, unless indicated otherwise in a credit line to the material. If material is not included in the article's Creative Commons licence and your intended use is not permitted by statutory regulation or exceeds the permitted use, you will need to obtain permission directly from the copyright holder. To view a copy of this licence, visit http://creativecommons.org/licenses/by/4.0/. The Creative Commons Public Domain Dedication waiver (http://creativecommons.org/publicdomain/zero/1.0/) applies to the data made available in this article, unless otherwise stated in a credit line to the data. 


\section{Introduction}

Pancreatic cancer (PC) is associated with poor clinical outcomes [1]. Surgical resection remains the mainstay therapy for PC; however, $<20 \%$ of patients are candidates for resection [2]. Moreover, even if a curative resection is performed, the 5-year survival remains relatively low [3-6]. Similarly, considering the high rate of postoperative local recurrence (LR) [7], most patients with PC will die because of local progression.

Recently, chemotherapy achieved some impressive advancements in treatment of PC $[8,9]$. Due to the progression in multidisciplinary therapy, the ability of local control may play increasingly important role in improving survival for PC. Fortunately, with the electron beam technique that became available in the past few decades [10, 11], intraoperative radiotherapy (IORT) has provided an effective method as part of multidisciplinary therapy in resectable PC.
The feasibility of IORT in cancer treatment was reported as early as 1905 by Comas and Prio [12]. IORT is a safe and effective procedure that can be administered without the risk of additional morbidity or mortality, and it has led to considerable improvement of local control [13]. However, other reports suggested that IORT was associated with more serious postoperative complications and was not associated with increased overall survival $[14,15]$. To date, the effect of IORT on longterm outcomes of resectable PC has not been completely determined. Thus, this meta-analysis aimed to compare the long-term outcomes of IORT versus non-IORT in patients with resectable PC.

\section{Methods and materials}

This meta-analysis was conducted according to the Preferred Reporting Items for Systematic Reviews and Meta-Analyses guideline [16].

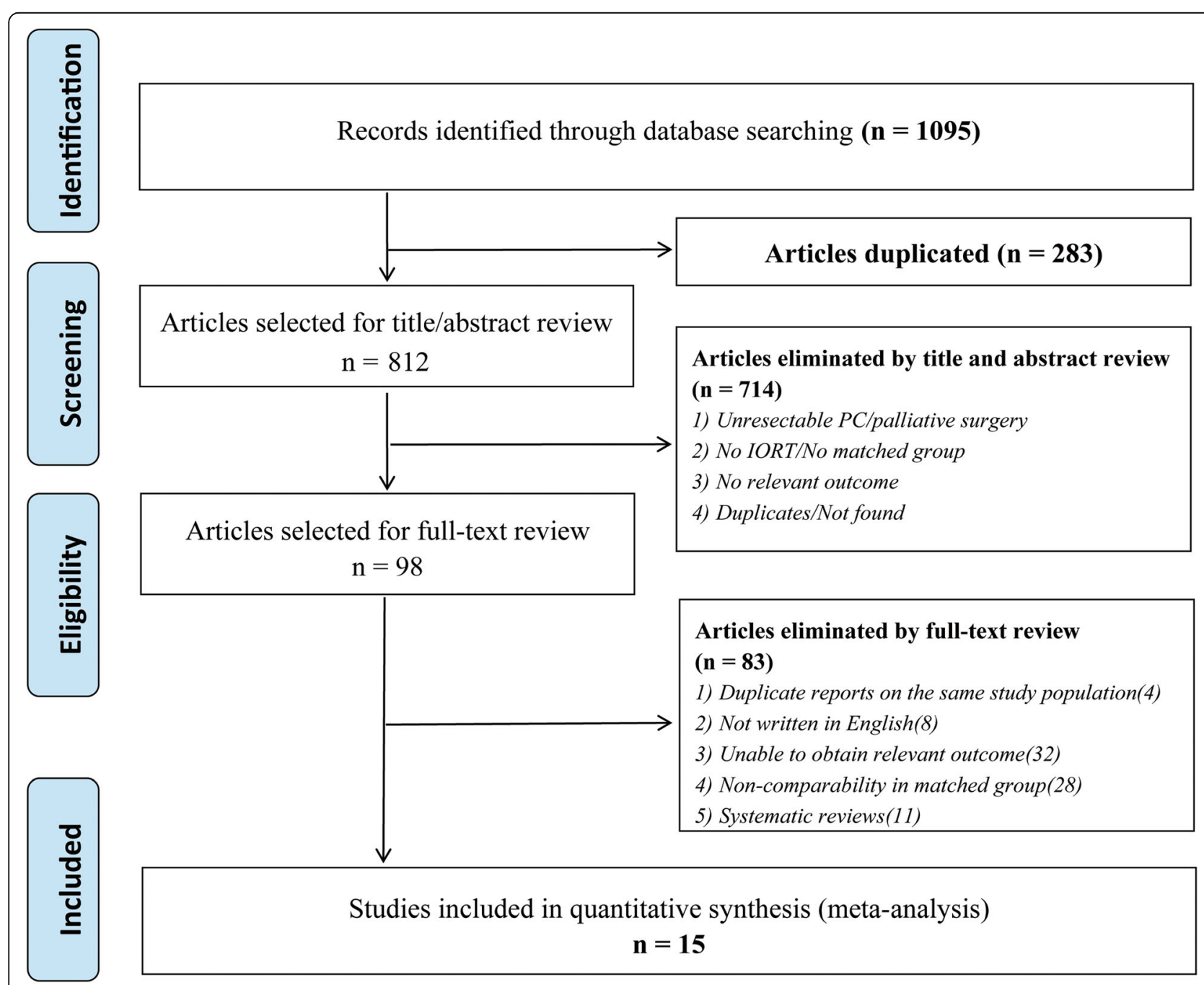

Fig. 1 Flow diagram of the literature search according to PRISMA guidelines 


\section{Data sources and search strategy}

We performed a computerized search of English-language publications listed in the electronic databases of MEDLINE/PubMed, EMBASE, and Cochrane Library to identify relevant studies published up to February 28, 2019. The following text and key words were used in combination to identify the studies: "pancreas cancer" and "intraoperative" and "radiotherapy." The full search strategy is provided in the Supplementary Material (File 1).

\section{Inclusion and exclusion criteria}

Studies included in our analysis had to (1) include resectable PC (without being metastatic or locally advanced); (2) include histologically proven PC; (3) contain two comparative groups (IORT vs. non-IORT); and (4) report the primary endpoints of the present meta-analysis (MST and LR). When several studies were reported by the same institution and/or authors, the publication with either the most complete data or that containing data with highest quality was selected for the meta-analysis. We excluded (1) studies wherein patients underwent palliative surgery; (2) studies reporting significant differences $(P<0.05)$ in tumor stages between the two comparative groups; (3) reviews without original data, duplicated publications, and animal studies; and (4) case reports, conference abstracts, review articles, and editorials.

\section{Study selection and outcome measures}

Articles were reviewed and cross-checked independently by two authors (LJ, NS). The title or abstract of studies initially selected by a systematic search were preliminarily screened, and then, full texts of potentially suitable studies were reviewed according to the inclusion criteria. Data on the following characteristics were independently extracted: author identification, publication year, study country, study design, study period, number of patients, and characteristics of the study population. The corresponding authors were contacted to verify the extracted data and to request for additional data if the required information was unavailable from the published article. Any discrepancies were resolved by a third investigator (XZJ) and were confirmed by consensus.

Two reviewers (LJ, NS) independently evaluated the quality of the observational studies using the Newcastle-Ottawa Scale criteria [17]. We developed the evaluation criteria using score ranging from 0 to 9 points for cohort and casecontrol studies, with higher score corresponding to a higher study quality. The primary endpoints of the present study were MST and LR, and the secondary endpoints were postoperative complications and operation-related mortality.

\section{Statistical analysis}

This meta-analysis was performed according to the recommendations of the Cochrane Collaboration and

Table 1 Characteristics of included studies comparing $\mathrm{S}+\mathrm{IORT}+\mathrm{EBRT}+\mathrm{CHT}$ versus $\mathrm{S}+\mathrm{EBRT}+\mathrm{CHT}$

\begin{tabular}{|c|c|c|c|c|c|c|c|c|c|c|c|c|c|c|c|c|c|c|c|}
\hline \multirow[t]{2}{*}{ Study } & \multirow[t]{2}{*}{ Nation } & \multirow[t]{2}{*}{$\begin{array}{l}\text { Study } \\
\text { design }\end{array}$} & \multirow[t]{2}{*}{$\begin{array}{l}\text { Study } \\
\text { period }\end{array}$} & \multicolumn{2}{|c|}{$\begin{array}{l}\text { Sample } \\
\text { size, } n\end{array}$} & \multicolumn{2}{|c|}{$\begin{array}{l}\text { Mean } \\
\text { age (year) }\end{array}$} & \multicolumn{2}{|c|}{ Male, \% } & \multicolumn{2}{|c|}{$\mathrm{CHT}, \mathrm{n}$} & \multicolumn{2}{|c|}{ EBRT, n } & \multicolumn{2}{|c|}{$\begin{array}{l}\text { Tumor } \\
\text { Size } \\
\text { (mean, } \\
\mathrm{cm} \text { ) }\end{array}$} & \multicolumn{2}{|c|}{$\begin{array}{l}\text { Median } \\
\text { Survival } \\
\text { Time } \\
\text { (month) }\end{array}$} & \multirow[t]{2}{*}{$\begin{array}{l}\text { Tumor Staging, } \mathrm{n} \\
(+) \text { vs. }(-)\end{array}$} & \multirow[t]{2}{*}{$\begin{array}{l}\text { Study } \\
\text { quality }\end{array}$} \\
\hline & & & & $(+)$ & $(-)$ & $(+)$ & $(-)$ & $(+)$ & $(-)$ & $(+)$ & $(-)$ & $(+)$ & $(-)$ & $(+)$ & $(-)$ & $(+)$ & $(-)$ & & \\
\hline $\begin{array}{l}\text { Dobelbower- } \\
11997 \text { [14] }\end{array}$ & USA & $\mathrm{R}$ & $\begin{array}{l}1980- \\
1995\end{array}$ & 10 & 14 & 58.4 & 60.5 & \multicolumn{2}{|c|}{$54.5 \%^{a}$} & 9 & 9 & 10 & 14 & 4.8 & 3.3 & 17.5 & 14.5 & $\begin{array}{l}\text { Stage I: } 1 \text { vs. } 4 \\
\text { Stage II: } 4 \text { vs, } 6 \\
\text { Stage III: } 6 \text { vs. } 4\end{array}$ & $* * * * * * * *$ \\
\hline $\begin{array}{l}\text { Nishimura } \\
1997 \text { [28] }\end{array}$ & Japan & $\mathrm{R}$ & $\begin{array}{l}1980- \\
1995\end{array}$ & 32 & 24 & \multicolumn{2}{|l|}{$62^{a}$} & NA & NA & 6 & 2 & 19 & 24 & NA & NA & 15.5 & 13.0 & $\begin{array}{l}\text { Stage I: } 13 \% \text { vs. } 8 \% \\
\text { Stage II: } 13 \% \text { vs. } 29 \% \\
\text { Stage III: } 48 \% \text { vs. } 39 \% \\
\text { Stage IV: } 28 \% \text { vs. } 24 \%\end{array}$ & $* * * * * *$ \\
\hline $\begin{array}{l}\text { Reni } 2001 \\
{[10]}\end{array}$ & Italy & $\mathrm{R}$ & $\begin{array}{l}1985- \\
1998\end{array}$ & 127 & 76 & 61.8 & 62.3 & 52 & 63.2 & 56 & 26 & 41 & 15 & 3.2 & 3.5 & 14.5 & 12.0 & $\begin{array}{l}\text { Stage I: } 5 \text { vs. } 4 \\
\text { Stage II: } 25 \text { vs, } 15 \\
\text { Stage III: } 55 \text { vs. } 35 \\
\text { Stage IV: } 42 \text { vs. } 22\end{array}$ & $* * * * * * *$ \\
\hline $\begin{array}{l}\text { Showalter } \\
2009[25]\end{array}$ & USA & PCD & $\begin{array}{l}1995- \\
2005\end{array}$ & 37 & 46 & 64 & 67 & NA & NA & 26 & 27 & 23 & 29 & NA & NA & 19.2 & 21.0 & $\begin{array}{l}\text { Stage I: } 7 \text { vs. } 16 \\
\text { Stage IIA: } 6 \text { vs. } 12 \\
\text { Stage } \geq \| \text { II: } 24 \text { vs. } 18\end{array}$ & $* * * * * *$ \\
\hline $\begin{array}{l}\text { Calvo } 2013 \\
{[22]}\end{array}$ & Spain & PCD & $\begin{array}{l}1995- \\
2012\end{array}$ & 29 & 31 & 60 & 62 & 58.6 & 64.5 & 18 & 19 & 29 & 31 & NA & NA & NA & NA & $\begin{array}{l}\text { Stage IB-IIA: } \\
13 \text { vs. } 16 \\
\text { Stage IIB-III: } \\
16 \text { vs. } 15\end{array}$ & $* * * * * * *$ \\
\hline $\begin{array}{l}\text { Keane } 2018 \\
{[29]}\end{array}$ & USA & $\mathrm{R}$ & $\begin{array}{l}2010- \\
2015\end{array}$ & 22 & 19 & $63^{a}$ & & $37^{a}$ & & 22 & 19 & 22 & 19 & $3.6^{a}$ & & 35.1 & 24.5 & $\begin{array}{l}41 \text { underwent resection } \\
\text { (no evidence of distant } \\
\text { metastases after NAT) }\end{array}$ & $* * * * * * *$ \\
\hline
\end{tabular}

$S$ indicates surgery, IORT intraoperative radiotherapy, EBRT external beam radiotherapy, $C H T$ chemotherapy, NAT neoadjuvant treatment $P C D$ prospectively collected data, $R$ retrospective case-matched study

${ }^{a}$ The Whole study; (+), IORT group; (-), Non-IORT group; NA no available; *represented one point, a score of 0 to 9 was assigned to each study and studies achieving a score of 6 or greater were considered high quality 
Meta-analysis of Observational Studies in Epidemiology guidelines [18]. Relative risks (RRs) were used to quantify the primary and secondary study observation endpoints. Summary RRs (95\% confidence interval $[\mathrm{CI}])$ were calculated by pooling study-specific estimates using a random-effects model that included between-study heterogeneity because significant heterogeneity was anticipated among studies. We calculated the $I^{2}$ (95\% CI) statistics to assess heterogeneity across studies, applying the following interpretation for $I^{2}:<50 \%=$ low heterogeneity; $50-75 \%=$ moderate heterogeneity; and $>75 \%=$ high heterogeneity [19]. The primary endpoint (MST) was analyzed using median survival ratio (MSR), which was the ratio of the median survival time between the two treatment groups $[20,21]$.

Table 2 Characteristics of included studies comparing S+ IORT versus S alone

\begin{tabular}{|c|c|c|c|c|c|c|c|c|c|c|c|c|c|c|c|}
\hline \multirow[t]{2}{*}{ Study } & \multirow[t]{2}{*}{ Nation } & \multirow[t]{2}{*}{$\begin{array}{l}\text { Study } \\
\text { design }\end{array}$} & \multirow[t]{2}{*}{$\begin{array}{l}\text { Study } \\
\text { period }\end{array}$} & \multicolumn{2}{|c|}{$\begin{array}{l}\text { Sample } \\
\text { size, } \mathrm{n}\end{array}$} & \multicolumn{2}{|c|}{$\begin{array}{l}\text { Mean age } \\
\text { (year) }\end{array}$} & \multicolumn{2}{|c|}{ Male, \% } & \multicolumn{2}{|c|}{$\begin{array}{l}\text { Tumor } \\
\text { Size } \\
\text { (mean, } \\
\text { cm) }\end{array}$} & \multicolumn{2}{|c|}{$\begin{array}{l}\text { Median } \\
\text { Survival } \\
\text { Time } \\
\text { (month) }\end{array}$} & \multirow[t]{2}{*}{$\begin{array}{l}\text { Tumor Staging, } n \\
(+) \text { vs. }(-)\end{array}$} & \multirow[t]{2}{*}{$\begin{array}{l}\text { Study } \\
\text { quality }\end{array}$} \\
\hline & & & & $(+)$ & $(-)$ & $(+)$ & $(-)$ & $(+)$ & $(-)$ & $(+)$ & $(-)$ & $(+)$ & $(-)$ & & \\
\hline Hiraoka 1990 [33] & Japan & $\mathrm{R}$ & $\begin{array}{l}1969- \\
1989\end{array}$ & 15 & 19 & 63.6 & 61.2 & 53 & 73.7 & NA & NA & 8.8 & 8.2 & $\begin{array}{l}\text { Stage I: } 0 \text { vs. } 2 \\
\text { Stage II: } 3 \text { vs. } 5 \\
\text { Stage III: } 9 \text { vs. } 7 \\
\text { Stage IV: } 3 \text { vs. } 5\end{array}$ & $* * * * * * *$ \\
\hline Shibamoto-1 1990 [26] & Japan & $\mathrm{R}$ & $\begin{array}{l}1975- \\
1989\end{array}$ & 2 & 31 & $60.1^{\mathrm{a}}$ & $60.9^{\mathrm{a}}$ & $48.7^{\mathrm{a}}$ & $67.9^{\mathrm{a}}$ & NA & NA & 8.5 & 9.0 & $\begin{array}{l}\text { Stage I: } 0 \text { vs. } 11^{\text {a }} \\
\text { Stage II: } 0 \text { vs. } 16^{\text {a }} \\
\text { Stage III: } 7 \text { vs. } 45^{\text {a }} \\
\text { Stage IV: } 7 \text { vs. } 40^{a}\end{array}$ & $* * * * * *$ \\
\hline Shibamoto-2 1990 [26] & Japan & $\mathrm{R}$ & $\begin{array}{l}1975- \\
1989\end{array}$ & 2 & 17 & $60.1^{\mathrm{a}}$ & $60.9^{\mathrm{a}}$ & $48.7^{\mathrm{a}}$ & $67.9^{\mathrm{a}}$ & NA & NA & 23.0 & 6.5 & $\begin{array}{l}\text { Stage I: } 0 \text { vs. } 11^{\text {a }} \\
\text { Stage II: } 0 \text { vs. } 16^{\text {a }} \\
\text { Stage III: } 7 \text { vs. } 45^{\text {a }} \\
\text { Stage IV: } 7 \text { Vs. } 40^{\text {a }}\end{array}$ & $* * * * * *$ \\
\hline Kawamura 1992 [30] & Japan & $\mathrm{R}$ & $\begin{array}{l}1978- \\
1990\end{array}$ & 8 & 13 & $67^{a}$ & $64^{\mathrm{a}}$ & $51.4^{\mathrm{a}}$ & $62.5^{\mathrm{a}}$ & NA & NA & 18.4 & 14.3 & $\begin{array}{l}\text { Stage I: } 2 \text { vs. } 6^{\mathrm{a}} \\
\text { Stage II: } 7 \text { vs. } 8^{\mathrm{a}} \\
\text { Stage III: } 28 \text { vs. } 26^{\mathrm{a}} \\
\text { Stage IV: } 0 \text { vs. } 0^{\mathrm{a}}\end{array}$ & $* * * * * * *$ \\
\hline Johnstone 1993 [31] & USA & $P$ & $\begin{array}{l}1980- \\
1984\end{array}$ & 7 & 4 & 61.5 & 59.4 & 25 & 71.4 & NA & NA & NA & NA & $\begin{array}{l}\text { Stage I: } 0 \text { vs. } 4 \\
\text { Stage II-IV: } 7 \text { vs. } 0\end{array}$ & $* * * * * *$ \\
\hline Kasperk 1995 [23] & Germany & $\mathrm{R}$ & NA & 12 & 18 & $62.5^{\mathrm{a}}$ & $64^{\mathrm{a}}$ & $69.7^{\mathrm{a}}$ & $70.7^{\mathrm{a}}$ & NA & NA & 10.9 & 12.2 & $\begin{array}{l}\text { All patients } \\
\text { (curative resection) }\end{array}$ & $* * * * * *$ \\
\hline $\begin{array}{l}\text { Dobelbower-2 } 1997 \\
\text { [14] }\end{array}$ & USA & $\mathrm{R}$ & $\begin{array}{l}1980- \\
1995\end{array}$ & 6 & 14 & 58.8 & 69.1 & $54.5^{\mathrm{a}}$ & & 4.9 & 4.7 & 9.0 & 6.5 & $\begin{array}{l}\text { Stage I: } 2 \text { vs. } 5 \\
\text { Stage II: } 2 \text { vs. } 5 \\
\text { Stage III: } 2 \text { vs. } 4\end{array}$ & $* * * * * * *$ \\
\hline Ouchi 1998 [27] & Japan & $\mathrm{R}$ & $\begin{array}{l}1982- \\
1996\end{array}$ & 5 & 6 & $64.7^{\mathrm{a}}$ & $61.0^{\mathrm{a}}$ & $66.7^{\mathrm{a}}$ & $100^{\mathrm{a}}$ & NA & NA & 8.0 & 14.0 & $\begin{array}{l}\text { Stage I: } 0 \text { vs. } 0 \\
\text { Stage II: } 1 \text { vs. } 1^{\text {a }} \\
\text { Stage III: } 5 \text { vs. } 6^{\text {a }} \\
\text { Stage IV: } 0 \text { vs. } 0\end{array}$ & $* * * * * * *$ \\
\hline $\begin{array}{l}\text { Takahashi } \\
1999[24]\end{array}$ & Japan & $\mathrm{R}$ & $\begin{array}{l}1985- \\
1997\end{array}$ & 16 & 32 & NA & NA & NA & NA & NA & NA & 10.0 & 9.0 & $\begin{array}{l}\text { Stage I: } 0 \text { vs. } 3 \\
\text { Stage II: } 1 \text { vs. } 4 \\
\text { Stage III: } 5 \text { vs. } 14 \\
\text { Stage IVA: } 6 \text { vs. } 8 \\
\text { Stage IVB: } 4 \text { vs. } 3\end{array}$ & $* * * * * * *$ \\
\hline Koukubo-1 2000 [15] & Japan & $\mathrm{R}$ & $\begin{array}{l}1980- \\
1997\end{array}$ & 34 & 39 & $63.0^{\mathrm{a}}$ & $63.0^{\mathrm{a}}$ & $60.1^{\mathrm{a}}$ & $60.1^{\mathrm{a}}$ & NA & NA & 15.0 & 11.0 & $\begin{array}{l}\text { All patients } \\
\text { (resectable) }\end{array}$ & $* * * * * * *$ \\
\hline Koukubo-2 2000 [15] & Japan & $\mathrm{R}$ & $\begin{array}{l}1980- \\
1997\end{array}$ & 7 & 14 & $63.0^{\mathrm{a}}$ & $63.0^{\mathrm{a}}$ & $60.1^{\mathrm{a}}$ & $60.1^{\mathrm{a}}$ & NA & NA & 8.0 & 6.0 & $\begin{array}{l}\text { All patients } \\
\text { (resectable) }\end{array}$ & $* * * * * * *$ \\
\hline Alfieri 2001 [32] & Italy & $\mathrm{R}$ & $\begin{array}{l}1985- \\
1995\end{array}$ & 26 & 20 & 62.5 & 58.4 & 40.0 & 42.3 & 3.04 & 2.73 & 14.3 & 10.8 & $\begin{array}{l}\text { Stage I: } 7 \text { vs. } 5 \\
\text { Stage II: } 5 \text { vs. } 5 \\
\text { Stage III: } 10 \text { vs. } 7 \\
\text { Stage IVA: } 4 \text { vs. } 3\end{array}$ & $* * * * * * *$ \\
\hline
\end{tabular}

Shibamoto-1 indicates R0 resection; Shibamoto-2, Non-R0 resection; Koukubo-1, R0 resection; Koukubo-2, Non-R0 resection

$S$ indicates surgery, IORT intraoperative radiotherapy, $P$ prospective study, $R$ retrospective case-matched study, NAT neoadjuvant treatment, NA no available

a, The Whole study; (+), IORT group; (-), Non-IORT group; * represented one point, a score of 0 to 9 was assigned to each study and studies achieving a score of 6

or greater were considered high quality 


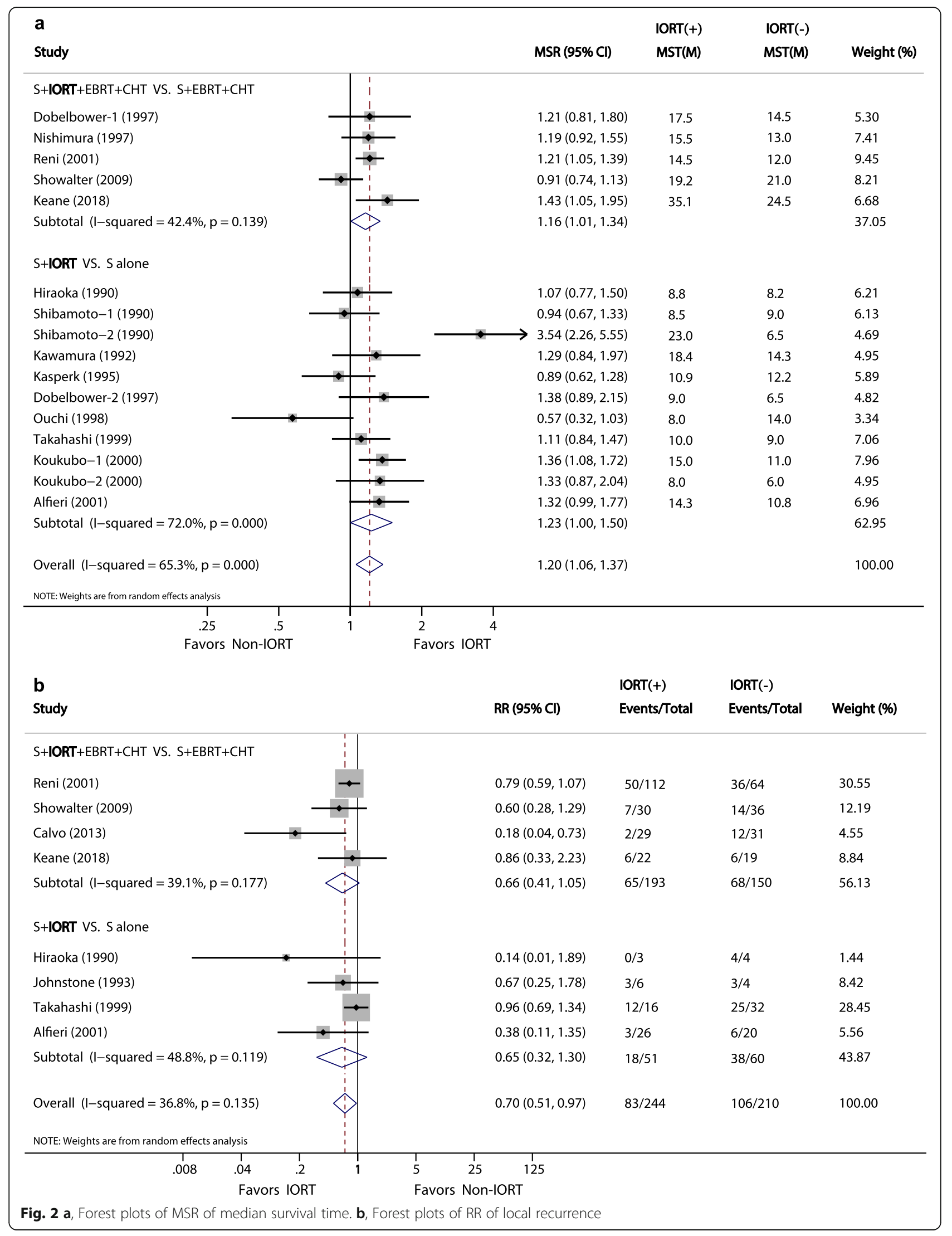


Subgroup analyses were performed to investigate potential sources of between-study heterogeneity. Publication bias, which was indicated with $P$ values $<0.10$, was assessed using funnel plots, and the tests were developed by Egger and Begg. All statistical analyses were performed using the Stata software, version 12.0 (STATA Corporation, College Station, TX, USA). Statistical analyses were twosided, and $P$ values $<0.05$ were considered statically significant.

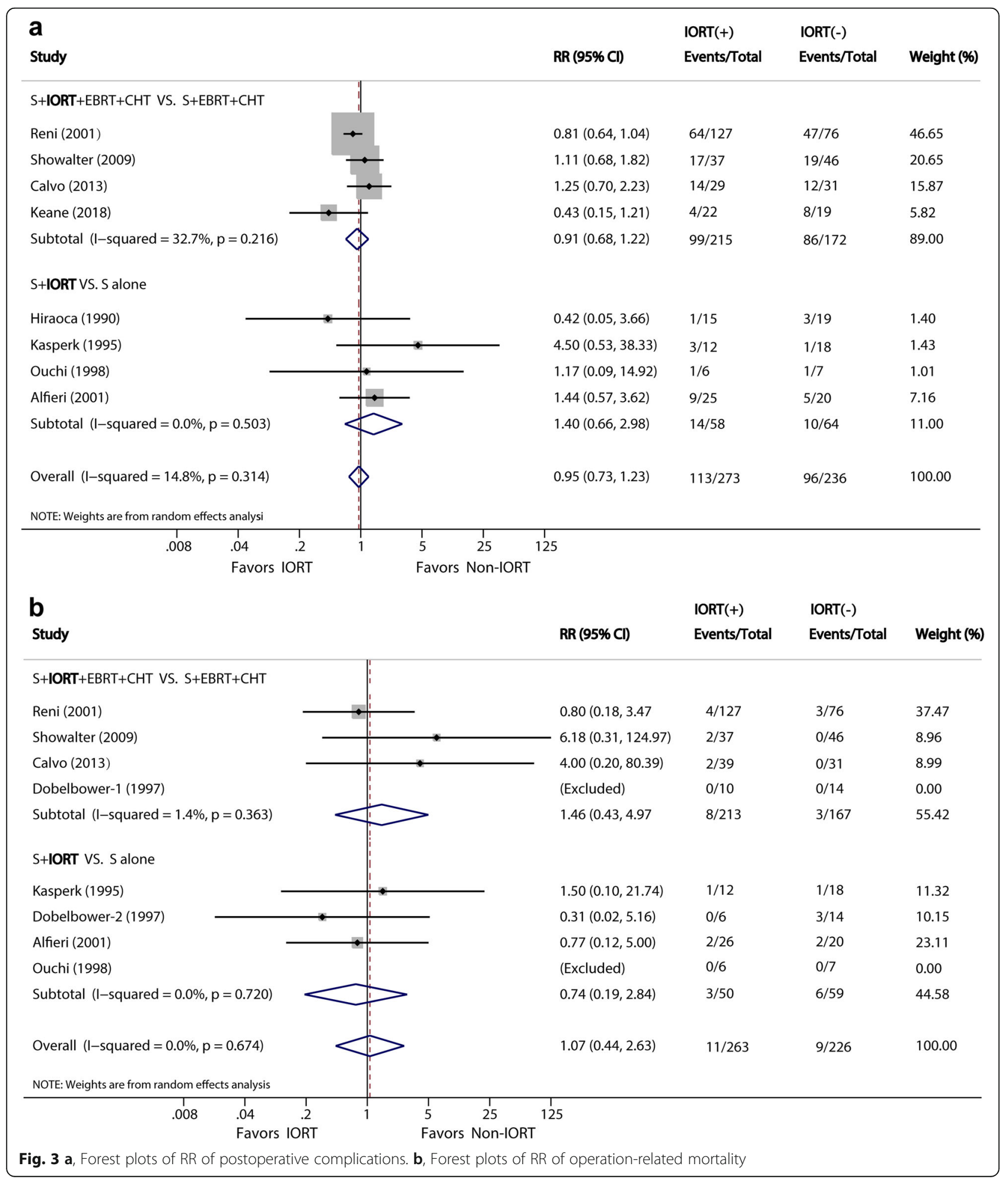


Table 3 Sensitivity Analysis Comparing IORT versus Non-IORT

\begin{tabular}{|c|c|c|c|c|c|c|}
\hline \multirow[t]{2}{*}{ Stratified analysis } & \multirow{2}{*}{$\begin{array}{l}\text { No. } \\
\text { Studies }\end{array}$} & \multirow{2}{*}{$\begin{array}{l}\text { No. } \\
\text { Patients }\end{array}$} & \multirow{2}{*}{$\begin{array}{l}\text { Pooled MSR/RR } \\
(95 \% \mathrm{Cl})\end{array}$} & \multirow[t]{2}{*}{$\boldsymbol{P}$ value } & \multicolumn{2}{|c|}{ Heterogeneity } \\
\hline & & & & & $\overline{P^{2}(\%)}$ & $\boldsymbol{P}$ value \\
\hline \multicolumn{7}{|c|}{ (1) Analysis for MST } \\
\hline \multicolumn{7}{|c|}{ By publication year: } \\
\hline After 2000y & 5 & 467 & $1.22(1.07$ to 1.40$)$ & 0.004 & 46.2 & 0.098 \\
\hline Before 2000y & 8 & 296 & $1.18(0.94$ to 1,49$)$ & 0.144 & 73.4 & 0.000 \\
\hline \multicolumn{7}{|l|}{ By sample size: } \\
\hline$>30$ & 9 & 617 & 1.17 (1.06 to 1.29$)$ & 0.002 & 29.0 & 0.187 \\
\hline$\leq 30$ & 6 & 146 & 1.28 (0.88 to 1.85$)$ & 0.195 & 80.6 & 0.000 \\
\hline \multicolumn{7}{|l|}{ By NOS score: } \\
\hline$>6$ & 10 & 594 & 1.27 (1.09 to 1.47$)$ & 0.002 & 64.1 & 0.001 \\
\hline$\leq 6$ & 3 & 169 & 1.00 (0.83 to 1.20$)$ & 0.970 & 27.9 & 0.250 \\
\hline \multicolumn{7}{|c|}{ By study location: } \\
\hline America & 3 & 168 & 1.18 (0.92 to 1.51$)$ & 0.189 & 56.7 & 0.074 \\
\hline Europe & 3 & 279 & 1.17 (0.99 to 1.39$)$ & 0.072 & 34.1 & 0.219 \\
\hline Asian & 7 & 316 & 1.24 (0.98 to 1.56$)$ & 0.068 & 75.1 & 0.000 \\
\hline
\end{tabular}

\section{(2) Analysis for LR}

By publication year:

$\begin{array}{ll}\text { After 2000y } & 5 \\ \text { Before 2000y } & 3\end{array}$

389

66

By sample size:

$\begin{array}{ll}>30 & 6 \\ \leq 30 & 2\end{array}$

By NOS score:

$\begin{array}{lll}>6 & 6 & 312 \\ \leq 6 & 2 & 77\end{array}$

By study location:

$\begin{array}{lll}\text { America } & 3 & 118 \\ \text { Europe } & 3 & 282 \\ \text { Asian } & 2 & 55\end{array}$

\section{(3) Analysis for complications}

By publication year:

$\begin{array}{lll}\begin{array}{l}\text { After 2000y } \\ \text { Before 2000y }\end{array} & 5 & 43 \\ & 3 & 77 \\ >30 & & \\ \leq 30 & 6 & 46\end{array}$

By NOS score:

$\begin{array}{lll}>6 & 6 & 396 \\ \leq 6 & 2 & 113\end{array}$

By study location:

$\begin{array}{lll}\text { America } & 2 & 124 \\ \text { Europe } & 4 & 338 \\ \text { Asian } & 2 & 47\end{array}$

466

43

396

113

124

338

47

$$
0.63 \text { (0.41 to 0.96) }
$$

0.033

0.77 (0.39 to 1.50$)$

0.439

0.72 (0.52 to 1.02)

0.061

0.316

0.43 (0.08 to 2.26)

0.69 (0.45 to 1.05)

0.082

0.127

0.62 (0.34 to 1.14 )

0.69 (0.41 to 1.14$)$

0.147

0.106

0.524

0.51 (0.06 to 4.08$)$

1.33 (0.32 to 5.46$)$

0.697
0.684

By sample size:

0.94 (0.71 to 1.25 )

0.92 (0.72 to 1.19$)$

2.57 (0.50 to 13.3$)$

0.543

0.259

0.87 (0.69 to 1.10 )

0.240

0.482

1.51 (0.48 to 4.82$)$

0.77 (0.31 to 1.93$)$

0.582

0.728

0.603

$1.08(0.70$ to 1.67$)$

0.65 (0.12 to 3.35$)$

0.603
33.4

0.199

37.9

0.200

43.3

0.117

43.2

0.185

52.4

0.062

0.0

0.862

0.841

0.0

0.055

65.5
64.8

0.092

value

001

0.00


Table 3 Sensitivity Analysis Comparing IORT versus Non-IORT (Continued)

\begin{tabular}{|c|c|c|c|c|c|c|}
\hline \multirow[t]{2}{*}{ Stratified analysis } & \multirow{2}{*}{$\begin{array}{l}\text { No. } \\
\text { Studies }\end{array}$} & \multirow{2}{*}{$\begin{array}{l}\text { No. } \\
\text { Patients }\end{array}$} & \multirow{2}{*}{$\begin{array}{l}\text { Pooled MSR/RR } \\
(95 \% \mathrm{CI})\end{array}$} & \multirow[t]{2}{*}{$\boldsymbol{P}$ value } & \multicolumn{2}{|l|}{ Heterogeneity } \\
\hline & & & & & $\overline{P^{2}(\%)}$ & $\boldsymbol{P}$ value \\
\hline \multicolumn{7}{|c|}{ (4) Analysis for Mortality } \\
\hline \multicolumn{7}{|c|}{ By publication year: } \\
\hline After 2000y & 4 & 392 & $1.20(0.43$ to 3.31$)$ & 0.726 & 0.0 & 0.503 \\
\hline Before 2000y & 3 & 87 & 0.71 (0.10 to 4.93$)$ & 0.727 & 0.0 & 0.417 \\
\hline \multicolumn{7}{|l|}{ By sample size: } \\
\hline$>30$ & 4 & 392 & 1.20 (0.43 to 3.31$)$ & 0.503 & 0.0 & 0.503 \\
\hline$\leq 30$ & 3 & 86 & 0.71 (0.10 to 4.93 ) & 0.417 & 0.0 & 0.417 \\
\hline \multicolumn{7}{|l|}{ By NOS score: } \\
\hline$>6$ & 5 & 366 & 0.84 (0.31 to 2.30$)$ & 0.731 & 0.0 & 0.671 \\
\hline$\leq 6$ & 2 & 113 & 2.80 (0.38 to 20.7) & 0.312 & 0.0 & 0.483 \\
\hline \multicolumn{7}{|c|}{ By study location: } \\
\hline America & 2 & 127 & 1.31 (0.07 to 25.0) & 0.856 & 51 & 0.153 \\
\hline Europe & 4 & 339 & 1.03 (0.38 to 2.81) & 0.951 & 0.0 & 0.780 \\
\hline Asian & 1 & 13 & Not estimable & Not estimable & Not estimable & Not estimable \\
\hline
\end{tabular}

MST indicates median survival time, $L R$ local recurrence, NOS Newcastle-Ottawa Scale

\section{Results}

\section{Characteristics of included studies}

Using the search strategy, 1095 unique articles were initially retrieved, of which 98 were considered of interest. The full texts of the 98 articles were retrieved for detailed evaluation, and finally, 15 studies complying with the inclusion criteria were assessed (Fig. 1).

Fifteen independent eligible studies [10, 14, 15, 2233] were included in the analysis, these studies included 834 patients who underwent pancreatic resection with IORT $(n=401)$ or without IORT $(n=433)$. The studies were published between January 1971 and February 2019. There was one prospective study, 12 retrospective case-matched studies, and two studies that used a prospectively collected database. Based on whether patients underwent neoadjuvant or adjuvant treatment, CHT, or external beam radiotherapy (EBRT), these studies were divided into two subgroups: surgery $(\mathrm{S})+\mathrm{IORT}+\mathrm{EBRT}+\mathrm{CHT}$ versus $\mathrm{S}+\mathrm{EBRT}+\mathrm{CHT}(n=6)$ and $\mathrm{S}+\mathrm{IORT}$ versus $\mathrm{S}$ alone $(n=12)$. The Dobelbower et al. [14] study contained more than two subgroups (the Dobelbower-1 represented $\mathrm{S}+\mathrm{IORT}+\mathrm{EBRT}+\mathrm{CHT}$ vs. $\mathrm{S}+\mathrm{EBRT}+$ CHT subgroup, the Dobelbower-2 represented $\mathrm{S}+$ IORT vs. S alone subgroup). Koukubo and Shibamoto et al. $[15,26]$ reported their results according to R0 and non-R0 resection respectively (Koukubo-1 and Shibamoto-1 represented R0 resection, Koukubo-2 and Shibamoto-2 represented non-R0 resection).

The Newcastle-Ottawa Scale score involving 15 studies was $\geq 7$, for the other four studies the score was equal to 6 , indicating that all of the included articles had high quality [34]. All of the included studies described independent, consecutive sampling of their cohorts. Characteristics of the included studies are listed in Tables 1 and 2 (For additional details see Tables 4 and 5 in Electronic Supplementary Material).

\section{Postoperative median survival time}

The MST was available in 13 studies [10, 14, 15, 2330, 32, 33]. Overall, patients receiving IORT experienced a remarkably improved MST compared with those who did not receive IORT (MSR, 1.20; 95\% CI, 1.06-1.37, $P=0.005)$, with a moderate heterogeneity $\left(I^{2}=65.3 \%\right)$. Analyses of the two subgroups showed consistent results that favored the IORT group over the non-IORT group. Patients who underwent $\mathrm{S}+$ IORT had a longer MST than those who only had surgery, although the statistical significance was marginal (MSR, 1.23; 95\% CI, 1.00-1.50, $P=0.05 ; I^{2}=$ $72 \%$ ), and patients who underwent $\mathrm{S}+$ IORT + EBRT + CHT had a significantly longer MST than those who were subjected to $\mathrm{S}+\mathrm{EBRT}+\mathrm{CHT}$ (MSR, 1.16; 95\% CI, 1.01-1.34, $P<0.05)$, with low heterogeneity $\left(I^{2}=42.4 \%\right)$ (Fig. 2a).

There was evidence of moderate heterogeneity of MSRs across the studies $\left(I^{2}=65.3 \% ; P<0.001\right)$. Risk estimates barely changed after analyses with fixed effects models, although the substantial heterogeneity remained.

\section{Local recurrence}

Eight studies [10, 22, 24, 25, 29, 31-33] investigated the association between IORT and postoperative LR. 
The pooled data showed a significantly reduced risk of LR associated with IORT (RR, 0.7; 95\% CI, 0.51$0.97 ; P=0.03$ ) (Fig. $2 b$ ). The results in the two subgroups were consistent, and the heterogeneity of the two subgroups was moderate $\left(I^{2}=39.1\right.$ and $48.8 \%$, respectively).

\section{Postoperative complications and operation-related mortality}

The incidences of postoperative complications were reported in 8 studies [10,22, 23, 25, 27, 32, 33]. The meta-analysis showed no significant difference between the IORT and non-IORT groups (41.4 vs. 40.7\%; RR, 0.95; 95\% CI, 0.73-1.23, $P=0.703$ ) (Fig. 3a). The subgroup analysis showed similar results in the two subgroups ( $P=0.534$ and 0.379 , respectively). The heterogeneity of these two subgroups was slight $\left(I^{2}=\right.$ $32.7 \%$ and 0 , respectively). The types of postoperative complications were described in detail in four studies $[10,23,27,32]$ that included 336 patients. Thirtyfour $(10.1 \%)$ of 336 patients had a pancreatic fistula as the most frequent complication. The second and third commonest complications were delayed gastric emptying (7.4\%) and abdominal infections (6.5\%).

Seven studies $[10,14,22,23,25,27,32]$ reported incidences of overall mortality. The meta-analysis indicated no significant difference in mortality $(4.3 \%$ vs. $4.0 \%)$ between the IORT and non-IORT groups (RR, 1.07; 95\% CI, 0.44-2.63) (Fig. 3b). The heterogeneity of these two subgroups was slight $\left(I^{2}=1.4 \%\right.$ and 0 , respectively).

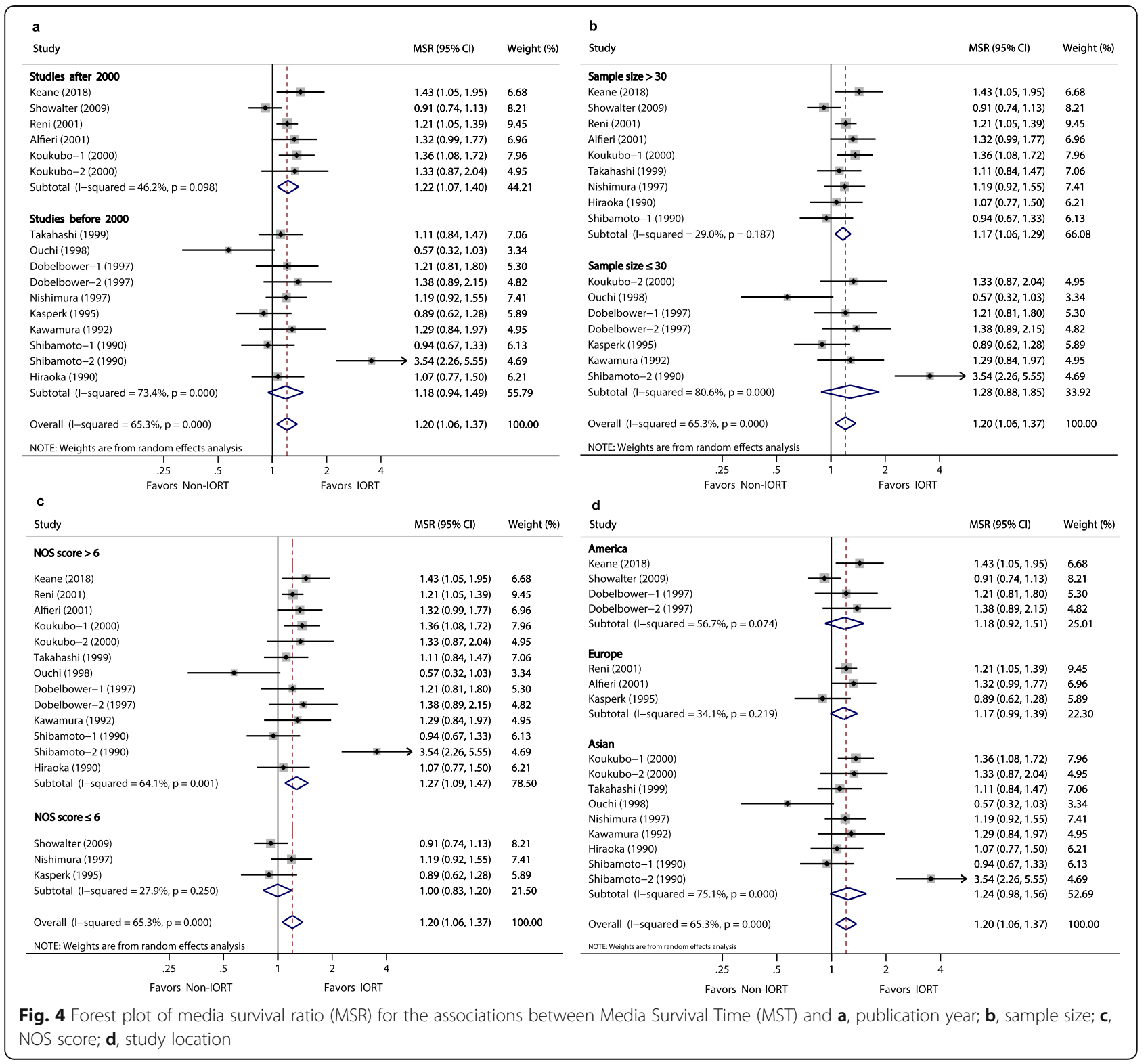




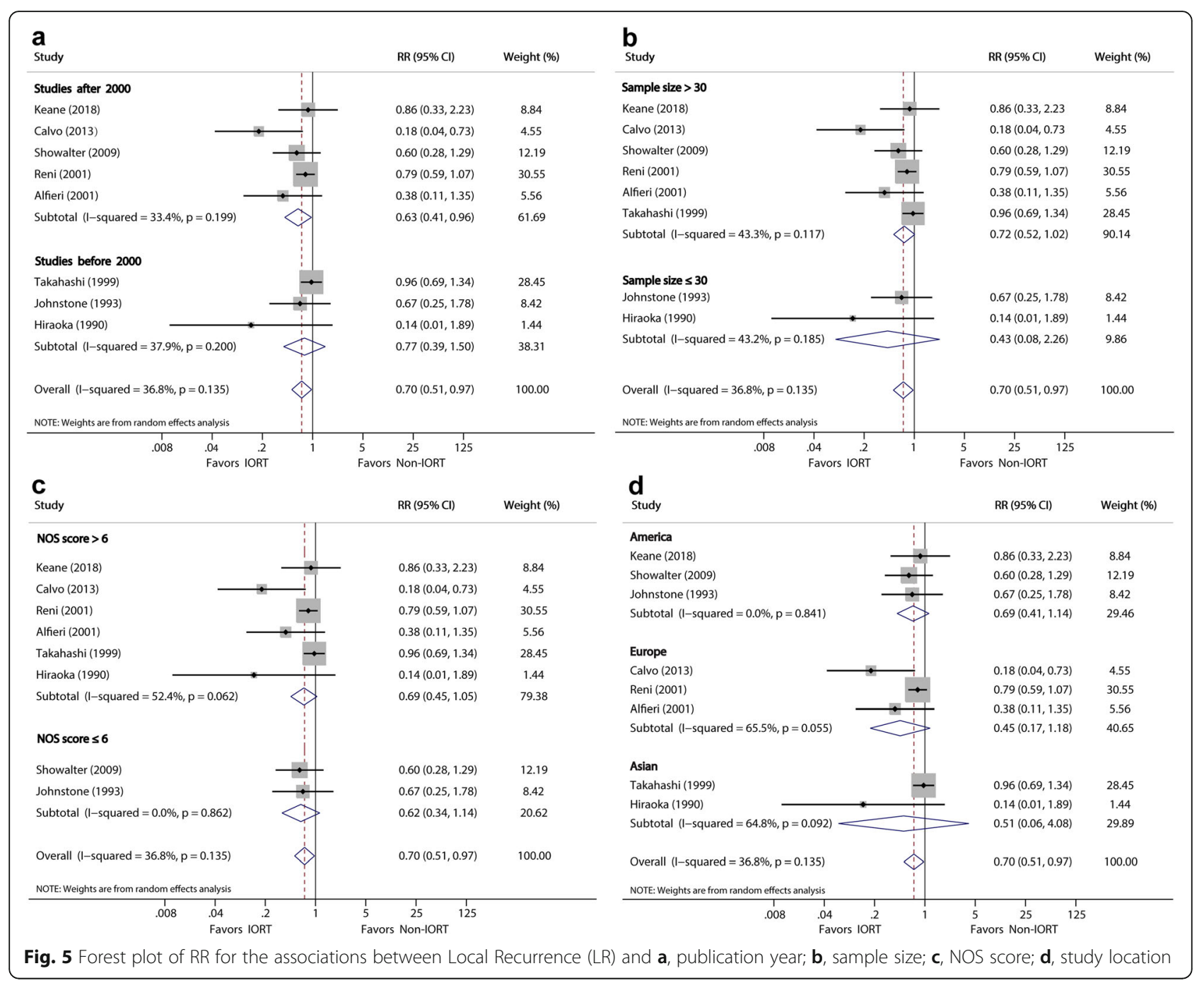

\section{Sensitivity analysis}

Subgroup analyses (Table 3 and Figs. 4, 5, 6 and 7) were performed using the publication year, sample size, study quality, and location in order to explore the potential source of heterogeneity found in these analyses. Subgroup analysis for MST showed a significant difference after year 2000 (MSR, 1.22, 95\% CI: 1.07-1.40; $P=0.004$ ), sample size $>30$ (MSR, 1.17, 95\% CI: 1.06-1.29; $P=0.002$ ), and NOS score $>6$ (MSR, 1.27, 1.09-1.47; $P=0.002)$. Subgroup analysis for LR showed a significant difference after year 2000 (RR, 0.63; 95\% CI, 0.41-0.96; $P=0.033$ ).

Sensitivity analysis was performed by sequentially omitting each study. The pooled MSR and 95\% CI were not significantly affected by removal of any single study in MST (Fig. 8a). For LR, postoperative complications, and operation-related mortality, the results were similar after the sequential exclusion of each study, which suggested the stability of the meta-analysis (Fig. 8b-d).

\section{Publication Bias}

Neither funnel plots nor Egger and Begg tests showed evidence of publication bias for the IORT versus nonIORT groups (Egger, $P=0.770$; Begg, $P=0.718$ ) with respect to MST and LR (Fig. 8e-f). After the trim-and-fill method, no additional risk estimate was needed to balance the funnel plot, and the summary effect estimate was not changed.

\section{Discussion}

The prognosis for patients with PC is dismal $[35,36]$. In recent years, the concept of multidisciplinary therapy has been proposed for treating PC. As a promising treatment strategy, IORT was introduced as a multimodality management approach to improve both tumor control and overall survival [1]. However, to date, the role of IORT in resectable PC has not been fully understood. To the best of our knowledge, the present study is the 

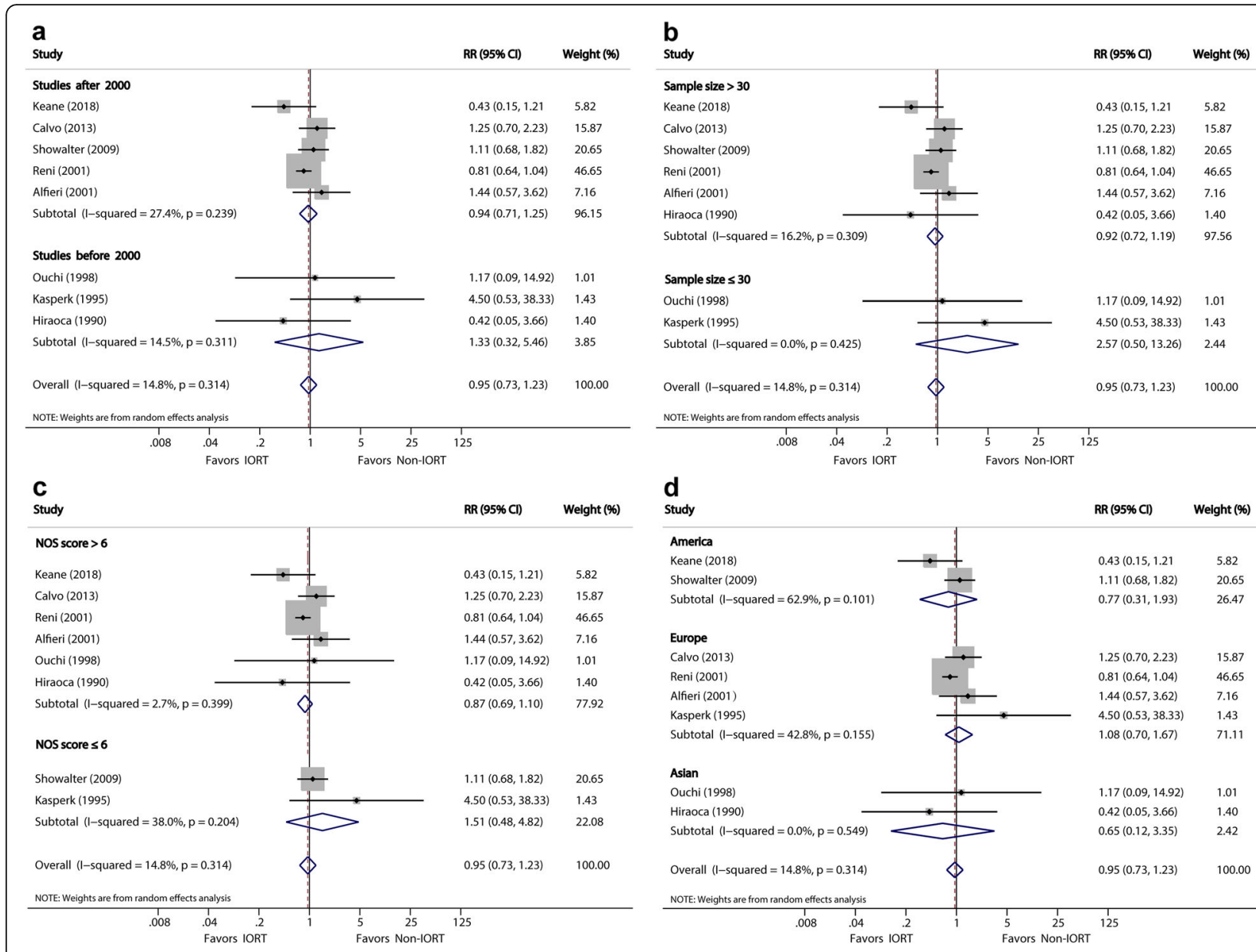

d

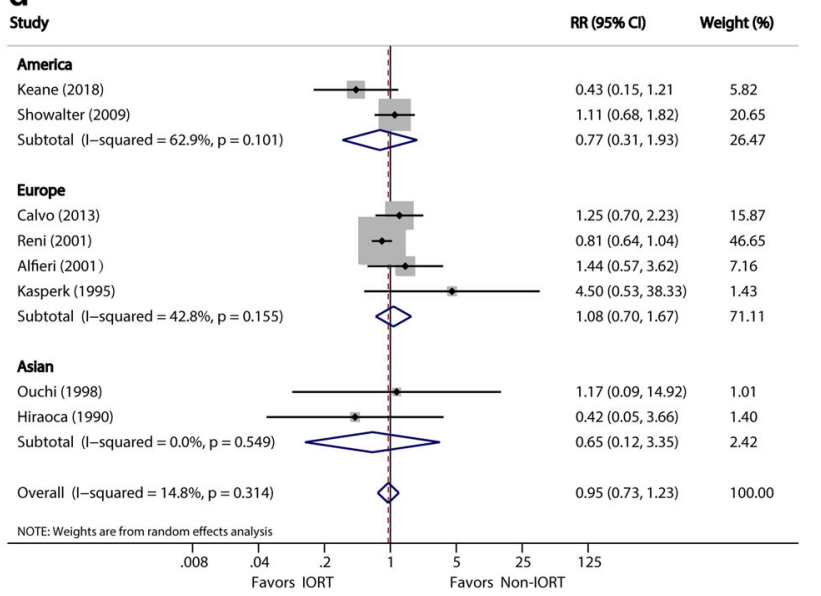

Fig. 6 Forest plot of RR for the associations between postoperative complications and a, publication year; $\mathbf{b}$, sample size; $\mathbf{c}$, NOS score; $\mathbf{d}$, study location

first meta-analysis that pooled the results of published research and compared the clinical outcomes in patients with resectable PC who underwent surgery with or without IORT.

LR appears to be the most frequent site of failure and is closely related to the survival rate of PC patients [37]. Our meta-analysis demonstrated that the application of IORT combined with surgery could decrease the LR rate.

Curative resection aiming for margin-negative (R0) status has been advocated to improve overall survival. However, even if a presumed R0 resection is performed, the local tumor recurrence rate remains high in resectable PC patients [38], suggesting that microscopic margin involvement is underestimated $[39,40]$. Fortunately, IORT can escalate the radiation dose to the tumor bed and spare adjacent normal tissues from radiation field. High radiobiological effects of IORT could prolong the induction of DNA damage and kill PC stem cell-like cancer cells, leading to the death of residual cancer cells and improvement of locoregional control [41].

The radiation dose that can be safely applied with EBRT is limited due to the tolerance of adjacent structures at risk and potential treatment-related complications. However, IORT has the advantage that it can be used to deliver additional radiation doses to deep-seated cancer residues or risk areas adjacent to radiosensitive critical organs, because these structures can be moved temporarily out of the radiation field.

With respect to overall postoperative survival rate, our meta-analysis indicated that patients who received IORT had a remarkable improvement in MST compared with those who did not receive IORT therapy $(P=0.005)$. In the $\mathrm{S}+\mathrm{IORT}$ versus surgery alone subgroups, MST was marginally longer in the IORT group than in the nonIORT group $(P=0.05)$. Nevertheless, in the $S+$ IOR$\mathrm{T}+\mathrm{EBRT}+\mathrm{CHT}$ versus $\mathrm{S}+\mathrm{EBRT}+\mathrm{CHT}$ subgroups, MST was significantly longer in the IORT group than in the non-IORT group $(P<0.05)$. 

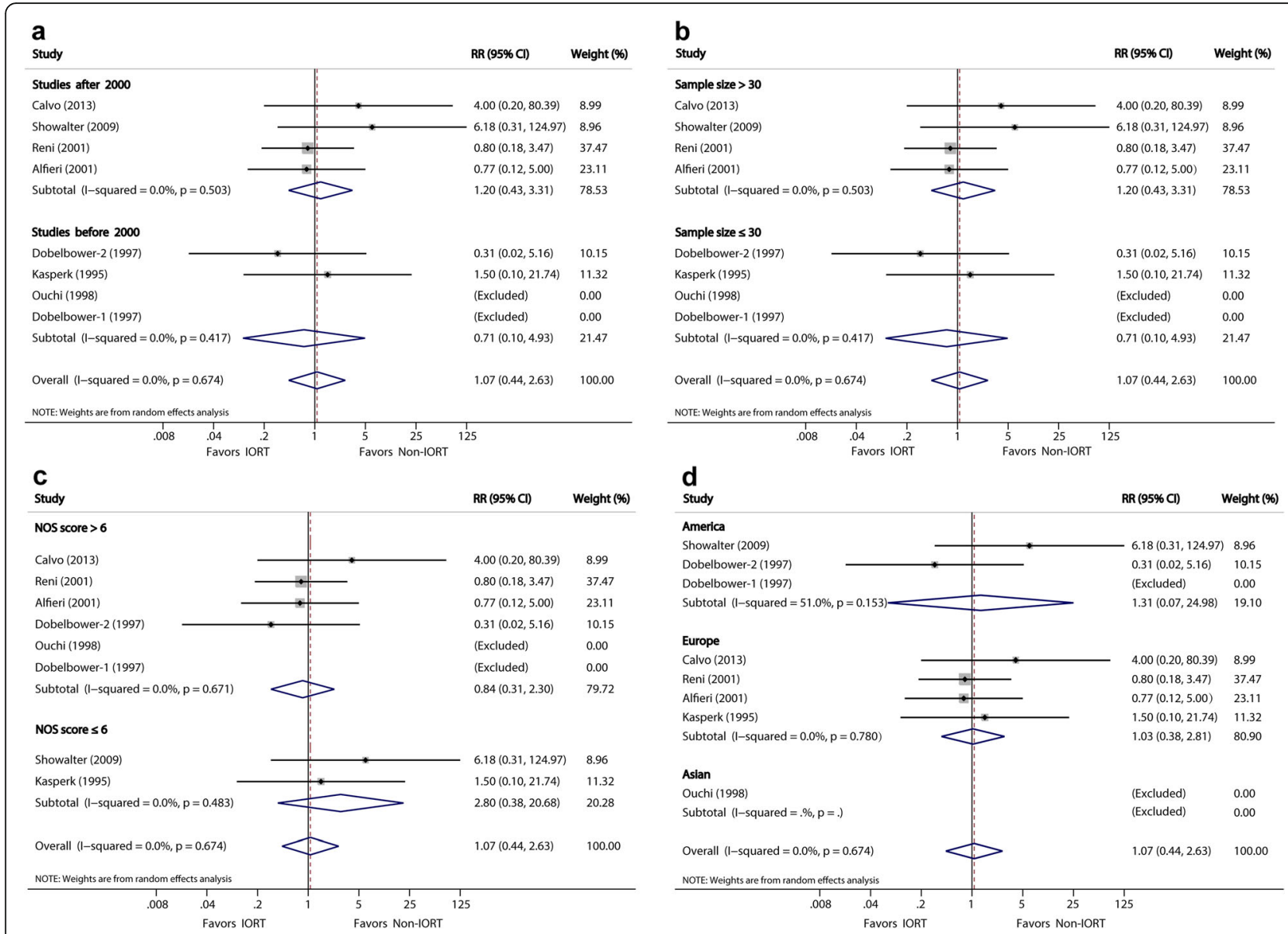

Fig. 7 Forest plot of RR for the associations between operation-related mortality and $\mathbf{a}$, publication year; $\mathbf{b}$, sample size; $\mathbf{c}$, NOS score; $\mathbf{d}$, study location

The strong ability of PC cells in potentially lethal injury repair (PLDR) and rejoining radiation-induced double-strand breaks (DSBs) results in their intrinsic resistance to radiation [42]. Radiotherapy sensitizers can enhance the radiation damage of DNA and interfere with the cell cycle proliferation [43]. Some studies have confirmed that CHT is a potent radiosensitizer that may promote radiotherapy sensitivity [44, 45]. In addition, as a boosting strategy, IORT combined with EBRT could achieve further dose escalation [46]. Calvo et al. [47] also reported that a combination of 15 Gy IORT boost with 45 Gy EBRT dose used in their study was biologically equivalent to $\geq 70 \mathrm{~Gy}$ EBRT in conventional fractionation. Consequently, the distinct advantage of IORT was in providing further dose escalation when it was used in combination therapy, which was a critical factor to improve local control and overall survival for patients with pancreatic cancer.

Several studies have shown favorable effects of IORT for treatment of patients with pancreatic cancer [10, 29, 48]. However, in the past, the widespread adoption of IORT was hindered due to limitations of beam energy, dose rate, and equipment availability [49]. Currently, the associated postoperative complications such as pancreatic fistula, delayed gastric emptying, and abdominal infections are additional factors that may affect clinical outcomes for PC patients [50]. Nonetheless, our metaanalysis showed that IORT did not cause an increase in postoperative complications and operation-related mortality, which occurred in $41.4 \%$ vs. 40.7 and $4.3 \%$ vs. $4.0 \%$ in both groups, respectively. IORT allows precise application of high radiation dose to the planning target volume (PTV) with minimal exposure of adjacent tissues, such as small intestine, liver, and kidney, to exorbitant radiotherapy dose. Therefore, IORT could be safely delivered to affected tissues in resectable PC during surgical resection. Although the current study does not provide a specific plan of combination therapy, our findings suggest that IORT should be considered as a potential component of an adjuvant multiple-treatment strategy. With this information, adjuvant systemic therapies for resectable PC should be further improved.

This meta-analysis had several limitations. First, most of the included trials had small sample sizes. 

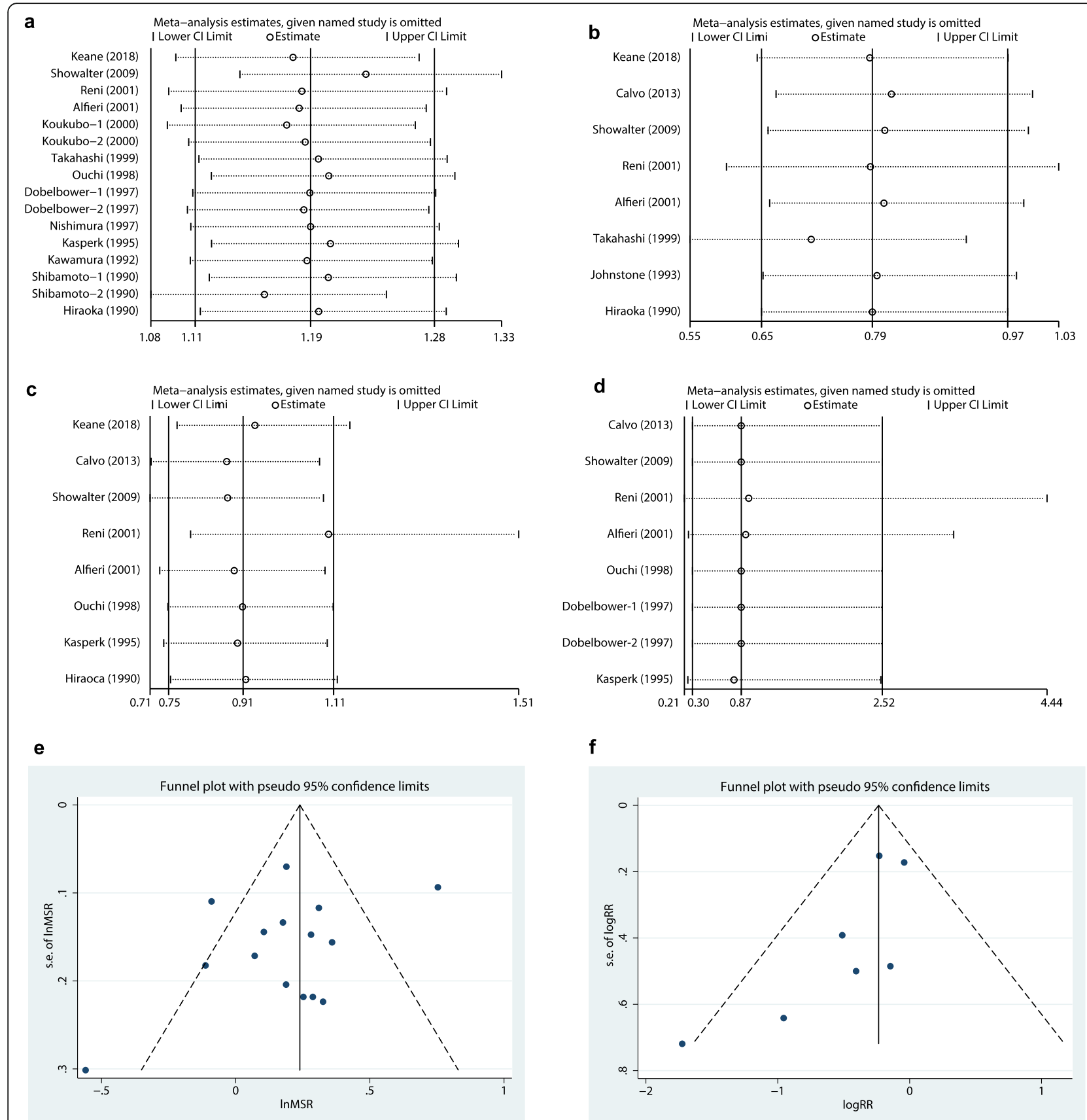

$\mathbf{f}$

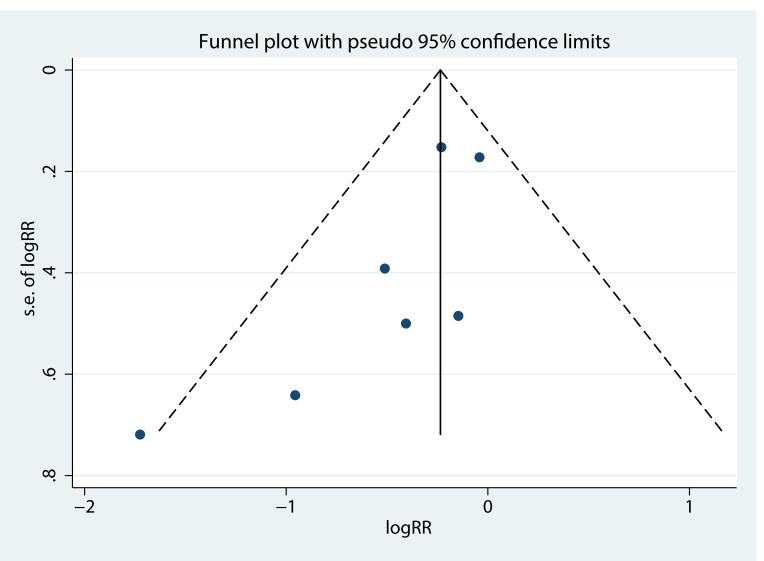

Fig. 8 Sensitivity analysis of meta-analysis: a, median survival time; $\mathbf{b}$, local recurrence; $\mathbf{c}$, postoperative complications; $\mathbf{d}$, operation-related mortality. Funnel plots for the assessment publication bias: e, median survival time; $\mathbf{f}$, local recurrence

Nevertheless, analysis of the pooled data clearly showed a superior effect of surgery combined with IORT with regards to MST and LR when compared to non-IORT groups. As postoperative complications and operationrelated mortality rates were similar between the two groups, applying IORT did not cause additional risks or side effects to the patients.

Second, there was substantial heterogeneity in our meta-analysis. In fact, owing to potential confounders, such as population characteristics, year of publication, the study sample sizes, etc., we conducted subgroup and sensitivity analyses to identify the source of heterogeneity and confirm the stability of our findings. Risk estimates barely changed after analyses with fixed effects models; however, substantial heterogeneity remained. When the analysis only included studies from selected periods when the publications were produced (before or after 2000), the overall polled data showed a significant 
difference that favored combined IORT (MSR, 1.20, 95\% CI: $1.06-1.37 ; P=0.005)$, especially for studies conducted after 2000 (MSR, 1.22, 95\% CI: 1.07-1.40; $P=$ 0.004 ), which appears to be attributable to combination therapy.

Using sensitivity analysis, the main source of heterogeneity was identified from the study by Shibamoto et al., wherein the imbalance of sample sizes between the IORT and non-IORT groups was significant $(n=4$ and 48, respectively). After excluding this single study, the heterogeneity reduced from moderate $\left(I^{2}=65.3 \%\right.$; $P=0.000)$ to low level $\left(I^{2}=30.6 \% ; P=0.132\right)$, and the pooled estimate still reached statistical significance (MSR $=1.17$; 95\% CI: $1.06-1.28, P=0.002$ ).

Third, most of the included studies in the present meta-analysis were retrospective analyses; thus, further large randomized controlled trials are warranted to confirm these findings.

\section{Conclusions}

In summary, this meta-analysis indicated that IORT significantly improved the locoregional control and overall survival for patients with resectable PC without increasing postoperative complications and operation-related mortality rate. Therefore, IORT is a safe and effective procedure that is associated with improved long-term clinical outcomes for patients with resectable PC. In addition, these findings demonstrated the importance of combination therapy.

\section{Supplementary information}

Supplementary information accompanies this paper at https://doi.org/10. 1186/s13014-020-01511-9.

\section{Additional file 1.}

\section{Abbreviations}

IORT: Intraoperative radiotherapy; PC: Pancreatic cancer; MST: Median survival time; LR: Local recurrence; MSR: Median survival rate; Cl: Confidence interval; RR: Relative risk; CHT: Chemotherapy; EBRT: External beam radiotherapy; S: Surgery; PLDR: Potentially lethal injury repair; DSBs: Double-strand breaks; PTV: Planning target volume; PRISMA: Preferred reporting items for systematic reviews and meta-analysis; M: Month

\section{Acknowledgements}

Not applicable.

\section{Authors' contributions}

Liang Jin and Ning Shi: design of the work; interpretation of data, statistic analysis and writing. Shiye Ruan and Baohua Hou: collection of clinical data and statistic analysis. Yiping Zou and Xiongfeng Zou: collection of clinical data. Haosheng Jin and Zhixiang Jian: design of the work and substantively revision of paper. The author(s) read and approved the final manuscript.

\section{Funding}

This study was supported by the Guangdong Medical Science and Technology Research Fund (A2018128).

\section{Availability of data and materials}

All data generated or analysed during this study are included in this published article [and its supplementary information files].

Ethics approval and consent to participate

Not applicable.

\section{Consent for publication}

Not applicable.

\section{Competing interests}

The authors declare that they have no competing interests.

Received: 14 January 2020 Accepted: 10 March 2020

Published online: 09 April 2020

References

1. Gillen S, Schuster T, Meyer Zum Buschenfelde C, et al. Preoperative/ neoadjuvant therapy in pancreatic cancer: a systematic review and metaanalysis of response and resection percentages. PLoS Med. 2010;7:e1000267.

2. Ryan DP, Hong TS, Bardeesy N. Pancreatic adenocarcinoma. N Engl J Med. 2014;371:1039-49.

3. Hidalgo M. Pancreatic cancer. N Engl J Med. 2010:362:1605-17.

4. Zaki Azzam A, Alqarni A, Mahmoud AT. The role of intraoperative radiotherapy (IORT) in the management of patients with pancreatic and periampullary cancer: a single center experience. J Egypt Natl Canc Inst. 2018;30:77-9.

5. Krempien R, Roeder F. Intraoperative radiation therapy (IORT) in pancreatic cancer. Radiat Oncol. 2017:12:8.

6. Valentini V, Calvo F, Reni M, et al. Intra-operative radiotherapy (IORT) in pancreatic cancer: joint analysis of the ISIORT-Europe experience. Radiother Oncol. 2009:91:54-9.

7. Song $X$, Shao $Z$, Liang $H$. Using the new INTRABEAM mobile intraoperative radiotherapy system during surgery for pancreatic cancer: a case report. J Med Case Rep. 2019;13:23

8. Tempero MA, Malafa MP, Al-Hawary M, et al. Pancreatic adenocarcinoma, version 2.2017, NCCN clinical practice guidelines in oncology. J Natl Compr Cancer Netw. 2017;15:1028-61.

9. Von Hoff DD, Ervin T, Arena FP, et al. Increased survival in pancreatic cancer with nab-paclitaxel plus gemcitabine. N Engl J Med. 2013;369:1691-703.

10. Reni M, Panucci MG, Ferreri AJM, et al. Effect on local control and survival of electron beam intraoperative irradiation for resectable pancreatic adenocarcinoma. Int J Radiat Oncol Biol Phys. 2001:50:651-8.

11. Coia LR, Hanks GE. The need for subspecialization: intraoperative radiation therapy. Int J Radiat Oncol Biol Phys. 1992:24:891-3.

12. C. Comas, P. A. Irradiation roentgen itraabdominale, après intervention chirurgicale dans un cas de cancer de l'uterus," in Congres International d'ElectrologieBarcelona: Imprenta Francesca Badia. 1907; 5-14.

13. Palta $M$, Willett $C$, Czito $B$. The role of intraoperative radiation therapy in patients with pancreatic cancer. Semin Radiat Oncol. 2014;24:126-31.

14. Dobelbower RR, Merrick HW, Khuder S, et al. Adjuvant radiation therapy for pancreatic cancer: a 15-year experience. Int J Radiat Oncol Biol Phys. 1997; 39:31-7.

15. Kokubo M, Nishimura $Y$, Shibamoto $Y$, et al. Analysis of the clinical benefit of intraoperative radiotherapy in patients undergoing macroscopically curative resection for pancreatic cancer. Int J Radiat Oncol Biol Phys. 2000:48:1081-7.

16. Page MJ, Moher D. Evaluations of the uptake and impact of the preferred reporting items for systematic reviews and meta-analyses (PRISMA) statement and extensions: a scoping review. Syst Rev. 2017;6:263.

17. Moher D, Liberati A, Tetzlaff J, et al. Preferred reporting items for systematic reviews and meta-analyses: the PRISMA statement. Ann Intern Med. 2009; 151:264-269, w264.

18. Stroup DF, Berlin JA, Morton SC, et al. Meta-analysis of observational studies in epidemiology: a proposal for reporting. Meta-analysis of observational studies in epidemiology (MOOSE) group. JAMA. 2000:283:2008-12.

19. Higgins JP, Thompson SG. Quantifying heterogeneity in a meta-analysis. Stat Med. 2002;21:1539-58.

20. Cortes J, Gonzalez JA, Campbell MJ, et al. A hazard ratio was estimated by a ratio of median survival times, but with considerable uncertainty. J Clin Epidemiol. 2014;67:1172-7. 
21. The confidence interval for the ratio of median survival times. https://www. graphpad.com/support/faq/the-confidence-interval-for-the-ratio-of-mediansurvival-times/. Accessed 10 Mar 2020.

22. Calvo FA, Sole CV, Atahualpa F, et al. Chemoradiation for resected pancreatic adenocarcinoma with or without intraoperative radiation therapy boost: long-term outcomes. Pancreatology. 2013;13:576-82.

23. Kasperk $R$, Klever $P$, Andreopoulos $D$, et al. Intraoperative radiotherapy for pancreatic carcinoma. Br J Surg. 1995:82:1259-61.

24. Takahashi S, Aiura K, Saitoh J, et al. Treatment strategy for pancreatic head cancer: pylorus-preserving pancreatoduodenectomy, intraoperative radiotherapy and portal catheterization. Digestion. 1999;60:130-4.

25. Showalter TN, Rao AS, Rani Anne $P$, et al. Does intraoperative radiation therapy improve local tumor control in patients undergoing pancreaticoduodenectomy for pancreatic adenocarcinoma? A propensity score analysis. Ann Surg Oncol. 2009;16:2116-22.

26. Shibamoto Y, Manabe T, Baba N, et al. High dose, external beam and intraoperative radiotherapy in the treatment of resectable and unresectable pancreatic cancer. Int J Radiat Oncol Biol Phys. 1990;19:605-11.

27. Ouchi K, Sugawara T, Ono H, et al. Palliative operation for cancer of the head of the pancreas: significance of pancreaticoduodenectomy and intraoperative radiation therapy for survival and quality of life. World J Surg Oncol. 1998;22:413-7.

28. Nishimura Y, Hosotani R, Shibamoto $Y$, et al. External and intraoperative radiotherapy for resectable and unresectable pancreatic cancer: analysis of survival rates and complications. Int J Radiat Oncol Biol Phys. 1997;39:39-49.

29. Keane FK, Wo JY, Ferrone CR, et al. Intraoperative radiotherapy in the era of intensive neoadjuvant chemotherapy and chemoradiotherapy for pancreatic adenocarcinoma. Am J Clin Oncol. 2018;41:607-12

30. Kawamura M, Kataoka M, Fujii T, et al. Electron beam intraoperative radiation therapy (EBIORT) for localized pancreatic carcinoma. Int J Radiat Oncol Biol Phys. 1992;23:751-7.

31. Johnstone PA, Sindelar WF. Patterns of disease recurrence following definitive therapy of adenocarcinoma of the pancreas using surgery and adjuvant radiotherapy: correlations of a clinical trial. Int J Radiat Oncol Biol Phys. 1993;27:831-4.

32. Alfieri S, Morganti AG, Di Giorgio A, et al. Improved survival and local control after intraoperative radiation therapy and postoperative radiotherapy: a multivariate analysis of 46 patients undergoing surgery for pancreatic head cancer. Arch Surg. 2001;136:343-7.

33. Hiraoka T. Extended radical resection of cancer of the pancreas with intraoperative radiotherapy. Baillieres Clin Gastroenterol. 1990;4:985-93.

34. Stang A. Critical evaluation of the Newcastle-Ottawa scale for the assessment of the quality of nonrandomized studies in metaanalyses. Eur J Epidemiol. 2010;25:603-5.

35. Chen W, Zheng R, Baade PD, et al. Cancer statistics in China, 2015. CA Cancer J Clin. 2016;66:115-32

36. Siegel RL, Miller KD, Jemal A. Cancer statistics, 2018. CA Cancer J Clin. 2018; 68:7-30.

37. Valentini $V$, Morganti AG, Macchia G, et al. Intraoperative radiation therapy in resected pancreatic carcinoma: long-term analysis. Int J Radiat Oncol Biol Phys. 2008;70:1094-9.

38. Verbeke CS, Gladhaug IP. Authors' reply: resection margin involvement and tumour origin in pancreatic head cancer (Br J Surg 2012; 99: 1036-1049). Br J Surg. 2013;100:299.

39. Campbell F, Smith RA, Whelan $P$, et al. Classification of $R 1$ resections for pancreatic cancer: the prognostic relevance of tumour involvement within $1 \mathrm{~mm}$ of a resection margin. Histopathology. 2009;55:277-83.

40. Buchler MW, Werner J, Weitz J. R0 in pancreatic cancer surgery: surgery, pathology, biology, or definition matters? Ann Surg. 2010;251:1011-2.

41. Oonishi K, Cui X, Hirakawa H, et al. Different effects of carbon ion beams and $\mathrm{X}$-rays on clonogenic survival and DNA repair in human pancreatic cancer stem-like cells. Radiother Oncol. 2012;105:258-65.

42. Gould MN, Howard SP. Radiosensitivity and PLDR in primary cultures of human normal and malignant mammary and prostate cells. Int J Radiat Biol. 1989:56:561-5.

43. Tabuchi S, Ozawa S, Koyanagi K, et al. Radiation-sensitizing effect of lowconcentration docetaxel on human esophageal squamous cell carcinoma cell lines. Exp Ther Med. 2011;2:601-6.

44. Rube CE, Dong $X$, Kuhne $M$, et al. DNA double-strand break rejoining in complex normal tissues. Int J Radiat Oncol Biol Phys. 2008:72:1180-7.
45. Small W Jr, Berlin J, Freedman GM, et al. Full-dose gemcitabine with concurrent radiation therapy in patients with nonmetastatic pancreatic cancer: a multicenter phase II trial. J Clin Oncol. 2008;26:942-7.

46. Roeder F, Timke C, Uhl M, et al. Aggressive local treatment containing intraoperative radiation therapy (IORT) for patients with isolated local recurrences of pancreatic cancer: a retrospective analysis. BMC Cancer. 2012; 12:295.

47. Calvo FA, Meirino RM, Orecchia R. Intraoperative radiation therapy first part: rationale and techniques. Crit Rev Oncol Hematol. 2006;59:106-15.

48. Roldan GE, Gunderson LL, Nagorney DM, et al. External beam versus intraoperative and external beam irradiation for locally advanced pancreatic cancer. Cancer. 1988;61:1110-6.

49. Krishnan S, Ahmad M. Intensifying local radiotherapy for pancreatic cancerwho benefits and how do we select them? J Gastrointest Oncol. 2013;4: 337-9.

50. Willett CG, Del Castillo CF, Shih HA, et al. Long-term results of intraoperative electron beam irradiation (IOERT) for patients with unresectable pancreatic cancer. Ann Surg. 2005;241:295-9.

\section{Publisher's Note}

Springer Nature remains neutral with regard to jurisdictional claims in published maps and institutional affiliations.
Ready to submit your research? Choose BMC and benefit from:

- fast, convenient online submission

- thorough peer review by experienced researchers in your field

- rapid publication on acceptance

- support for research data, including large and complex data types

- gold Open Access which fosters wider collaboration and increased citations

- maximum visibility for your research: over $100 \mathrm{M}$ website views per year

At BMC, research is always in progress.

Learn more biomedcentral.com/submissions 